have since been regularly continued. The examination is always held in England. The successful candidates receive a national diploma in the science and practice of agriculture.

Such, then, is the history of the diploma of which we are at present speaking. It is, of course, obvious that any society or societies may hold an examination in any subject they please, and grant certificates to successful candidates; but may such bodies, without proper authority, presume to confer a national diploma? That is the serious question before us. The charter of the Highland Society undoubtedly authorises it to confer a diploma in agriculture in Scotland, but the language of its charter, which we have already quoted, clearly limits its authority to that country. This fact is so manifest that we are now told by the agricultural Press that the Highland Society intends to apply to His Majesty's Government for an extension of its charter. The charter of the English Society contains no authority to grant diplomas.

We have already said that a national diploma in agriculture appears to us as a desirable thing, if it could be granted by national authority and awarded only to thoroughly trained men. If powers to grant such a diploma are now being sought, the terms of the charter granted many years ago to the Highland Society supply some pertinent suggestions. If the diploma is to be really national, if it is to be stamped with a national authority, the schemes of education and examination laid down must not be decided on by the members of two agricultural societies. The charter of the Highland Society names six professors of the University of Edinburgh as members of the education committee. A charter granted with a similar object now would naturally take a similar line, but it would not limit itself to the University of Edinburgh. The ex officio members of a national committee should clearly include professors from other British Universities, and representatives of the Government Boards of Agriculture and Education. Until such a general body is constituted and authorised to grant diplomas, it is a misuse of language to speak of a national diploma in agriculture or dairying.

We turn now to the character of the examination at present held for the award of the so-called national diploma. If the diploma granted merely professed to be an agricultural societies' diploma, it would be scarcely necessary to speak on the subject; but the claim to national rank surely implies a diploma examination of first-rate quality, and if it fails of this it certainly demands public criticism.

The diploma in question is granted solely on the result of examinations, no previous course of training being required. The examinations for the diploma embrace many branches of elementary science; half of the subjects are taken by the candidate in his first year and half in his second year. The syllabuses published of the subjects for examination are undoubtedly meagre, some of them strikingly so. This is a real disadvantage, as the teachers who are preparing students for these examinations naturally limit their instructions to the syllabus. The examinations are both written and oral, but include no laboratory work. In each subject the written examination is limited to two hours, save in the case of practical agriculture to which three hours are allotted. The candidates are generally directed to attempt every question in the paper, six to ten questions being set. The whole of the subject of practical agriculture is dealt with in one paper of three hours, followed by an oral examination. The tests applied by the examiners would thus appear to be decidedly superficial. The number of marks allotted to each subject must be sup- posed to indicate their relative importance in the eyes of the examining board. We find that book-keeping and agricultural chemistry receive the same number of marks, while general chemistry and veterinary science each receive half as many marks as book-keeping! It is, indeed, essential that anyone who is to practise tarming should pass an examination in book-keeping, but that a knowledge of agricultural chemistry should be taken to represent no greater previous study or no greater fitness for dealing with the problems of agriculture than a mastery of the art of posting trade accounts is certainly remarkable, and surely indicates a low appreciation of agricultural science by the examining board.

We have now done. The questions we have raised demand earnest attention. The character of our whole system of agricultural education depends on the standard set by what is apparently its highest grade. The present diploma has been given a title to which it has no right, and it has failed to justify by its excellence the rank which has been sought for it.

\section{THE INTERNATIONAL CONGRESS FOR APPLIED CHEMISTRY.}

THE fifth International Congress for Applied

Chemistry, which sat in the Reichstags-Gebäude of Berlin from June 2 to 8 under the masterly presidency of Dr. Otto N. Witt, professor at the Technical High School of Charlottenburg, will be remembered as a great representative meeting. The actual attendance figure was not announced, probably because many of the members who had previously secured their tickets forgot to enter their names on arrival. But the figure cannot much fall short of 2700 . Preparations had originally been made for I500 members. About 2500 had arrived by the time of the opening of the Congress, and those joining later could not be favoured with invitations to the many pleasant receptions and excursions which had been arranged. Everything possible was, however, done by the local committee, over which Dr. J. E. Holtz presided, and by the general secretaries, Dr. Pulvermacher and T. Karwath. Everybody could gain admission to the grand "Commers." The Diet had made a grant of $x_{5}, 000$ marks, donations had poured in from many sides, and private hospitality was practised most liberally. Chemical works, in the strict sense of the word, were not opened to members, but visits to special exhibitions, scientific institutes, and manufactories would have supplied an amply long and instructive programme even if the sectional proceedings had left members far more spare time than they did. Some sections deliberated from 9 to $x$, and again from 3 to 6 and later. The ladies were excellently taken care of during the whole congress week.

Though a more suitable and dignified place for the meeting could not have been found than the magnificent palace of the Imperial Diet, the large committee rooms of which afforded ample accommodation for all the sections, a parliament building is not a laboratory, and some of the sections had to emigrate for their experimental demonstrations. Section vii., fermentation and starch, sat mostly in the Institute for Fermentation, and had an exhibition of its own in the grounds adjoining this institute. Section ix., photochemistry, was isolated-and rather neglected, tooin the Technical High School at Charlottenburg. Section x., electrochemistry and physical chemistry, found a home in the Physical Institute of the University, close to the Reichstag. Each section had its official luncheon restaurant. The plenary meetings took place in the large hall of the Reichstag. 
On Tuesday evening, June 2, President Witt welcomed the members in German, French, and English. The formal opening meeting on the next morning, at which Prince Frederick Henry represented the Emperor, was addressed by Prof. Wıtt; Secretary of State Count Posadowsky-Wehner, on behalf of the Empire; the Prussian Minister of Education, Dr. Studt; Mayor Dr. Reicke, on behalf of the City of Berlin; representatives of the learned and technical bodies which had taken part in the organisation; and the official delegates, Dr. Tilden speaking for Great Britain. As thirty Governments had sent delegates, the representative of Switzerland, Prof. Lunge, was heard as speaker for the minor States. There was a beautiful passage in President Witt's eloquent welcome: The flames of special research burn in the many chapels, and the Congress unites all the worshippers of the one universal science. Mayor Reicke also earned warm applause. The honorary president of the Congress, the veteran chemist Prof. Clemens Winkler, was not well enough to attend. The vice-presidents were Drs. H. Böttinger, M Delbrück, C. von Martius, E. A. Merck. The honorary vice-presidents, Moissan, Meldola, Piutti, and Christomanos, were appointed by acclamation.

The second plenary meeting on Friday morning was devoted to lectures. H. Moissan demonstrated some of the properties of the alkali hydrides which he has recently prepared. Potassium hydride is a snowy mass, which has to be kept in sealed tubes, and decomposes, when heated, into potassium and hydrogen; a tube was broken under water to exemplify this. Carbonic acid gas decomposes the mass, but the decomposition does not occur in the second of two tubes joined in series, because the presence of a trace of moisture in the $\mathrm{CO}_{2}$ is necessary, nor does it occur below $-65^{\circ} \mathrm{C}$. The $\mathrm{KH}_{2}$ does not conduct the electric current, not even when fused, and the hydrogen in these alloys does not behave like a metal any more than it resembles metal in its liquid state.

Sir William Crookes then gave his discourse on modern views on matter: the realisation of a dream, dealing with speculations which the mysterious radioactive emanations suggest or support, and alluding to a fatal atomic dissociation which works when we brush a piece of glass with silk, and in sunshine and raindrops, in lightning and flames; protyle the formless mist, might once more reign supreme.

$J$. H. van 't Hoff then explained how the phase-law of Willard Gibbs enables us to understand the formation of natural salt deposits, referring to the influence of temperature, pressure, and time; the higher the basicity of the acid and the valency of the metal, the longer can a state of supersaturation exist, and when we have dibasic acids and bivalent metals, the addition of a solid crystal of the respective salt will no longer produce the crystallisation which is instantaneous in the case of Glauber salt.

The retrospective view of the ammonia-soda process, by $\mathrm{E}$. Solvay (Brussels), did not enter into any detail. In the next lecture, on auto-oxidation, Carl Engler (Karlsruhe) went in a certain measure back to Schönbein's ozone and antozone. Oxygen does not appear to combine in single atoms, but always as a whole molecule, giving an unsaturated compound which yields a peroxide; this peroxide then, by giving off half of its oxygen, forms oxides, and we may distinguish two classes of bodies in this respect. The auto-oxidators bind the oxygen to peroxide and pass half of it on to the acceptor, which itself cannot bind the atmospheric oxygen. We have thus, in the animal and vegetable kingdoms, to which these arguments particularly apply, peculiar catalytic processes. Engler made reference to a paper, read by $L$. Woehler
(Karlsruhe), who has extracted 18 per cent. of $\mathrm{Pt}$ from spongy platinum by hydrochloric acid, precipitated a protohydrate from the solution, and oxidised platinum, both as foil and sponge, by heating it in oxygen; a piece of foil absorbed I.9 per cent. of oxygen in thirty-seven days.

The last general lecture was given by G. Kraemer, of Berlin, on coal tar researches.

The concluding plenary meeting had to pass or reject the sectional resolutions which are to be presented to the permanent committee of the International Congresses for Applied Chemistry, and also to select the place for the next meeting. Most of the numerous resolutions, concerning the drawing up of analytical reports, the undesirability of characterising reagents simply as pure, the specialisation of the Trauzl test (explosions within lead chambers), the transport of explosives, a uniform method of compiling statistics of accidents, the soda test of petroleum, the prohibition of additions of starch to press yeast, and other points were approved of without discussion. The electrochemical units, recommended by Nernst, Warburg, and Strecker, on behalf of the Bunsen Gesellschaft, the Physical Society, and the Elektrotechnische Verein of Berlin, for general use in publications, were adopted by the Congress, with an amendment by $A$. A. Noyes (Boston) that a committee of the Bunsen Gesellschaft should cooperate with other societies in order to make the system more comprehensive. The proposals of Section xi., legal and economical questions, however, met with opposition. It was not unreasonably complained that the resolutions were not in print before the meeting, though they had been published in the daily journals-not always in their final versions, however-and the meeting declined to sanction: that the registration as trade marks of words is not to be considered illegal for the reason that those words had previously been used in a definite sense. The assembly agreed to the general prohibition of white phosphorus matches, and recommended proper care of the employés in chemical works as a moral obligation the observance of which would serve the manufacturer's own interest. The two International Commissions, for analysis (created in 1900, chairman, Prof. Lunge) and for manures and fodders (created in 1898, chairman, Dr. von Grueber; of Malmö) were reappointed. The sugar chemists wished to settle their analytical methods for themselves. A new commission is to be elected for compiling a codex alimentarius.

The remarkable skill, tact, and firmness with which President Witt guided the assembly in these discussions were again called into requisition when the place of the next meeting was to be decided. On behalf of the Italian Government, the City of Rome, and the learned societies of Italy, Prof. Paterno di Sessa invited the congress to Rome. In accordance with a resolution unanimously passed by the British members of the Congress in a special meeting, at which thirty-eight members were present, Mr. I. Levinstein, president of the Society of Chemical Industry, asked the Congress to come to London in I906, on behalf of that society and other societies interested; Dr. Tilden, the British delegate, supported the invitation. Both Italy and Great Britain had previously offered hospitality to the Congress, Italy, it would appear, twice, England once. The question was finally decided by a regular division, after the manner of the German Reichstag, when 294 members voted for Rome and 274 for London.

The sectional proceedings were conducted on the lines of the German Naturforscher-Versammlung. The presidents of the eleven sections and four subsections were almost all Berlin men. Their names 
are:-(I.) Analytical chemistry, G. von Knorre; (2) inorganic chemical products, A. Heinecke, director of the Berlin porcelain manufacture; $\left(3^{a}\right)$ mining and metallurgy, G. Weeren; $(3 b)$ explosives, W. Will; $(4 a)$ organic products (including tar), $H$. Wichelhaus; (4b) dyes, A. Lehne; (5) sugar, A. Herzfeld; (6) fermentation and starch, M. Delbrück; (7) agricultural chemistry, O. Kellner; (8) Hygiene, E. A. Merck; subsections $(a)$ foods, K. von Buchka; $(b)$ pharmacy, H. Thoms; (c) hygiene, M. Rubner; (9) photochemistry, A. Miethe; (ro) electro- and physical chemistry, H. Böttinger (of Elberfeld); (II) legal and economical questions, C. A. von Martius. Before adjourning each day, the sections, however, nominated the president and vice-presidents for the following meeting. As a result, the time limits, twenty minutes for the reading of a paper, five minutes for each speaker, were not well adhered to. Each speaker is at once presented with a slip of paper on which he is to condense his remarks for publication in the daily journal or later in the reports. Some sections gave brief abstracts of the proceedings in the daily journals, others merely stated titles of papers and names of authors and speakers. A not inconsiderable number of the 457 reports and papers announced were not read owing to the-frequently only momentary-absence of the authors. Brief abstracts of some of the most important papers will follow.

H. BORNS.

\section{NOTES.}

THE annual conversazione, or ladies' soirée, of the Royal Society will be held on Friday, June 19.

Prof. J. J. Thomson has had the honorary degree of doctor of science conferred upon him by the Columbia University, New York.

Sir Otiver Lodge delivered the Romanes lecture in the Sheldonian Theatre, Oxford, on Friday last, on the subject of "Modern Views of Matter."

A GRNeral meeting of the Institution of Mining Engineers will be held in London on Thursday, July 2, and the following day in the rooms of the Geological Society.

Mr. E. T. Whrttaker, of Trinity College, Cambridge, will deliver an address before the Mathematical Society of University College, London, on Thursday, June 25, at 5.30 p.m., on "Some Present Aims and Prospects of Mathematical Research."

THE Moniteur Officiel du Commerce of Paris announces that an International Exhibition of the Industrial Appliances of Alcohol will be held at Rio de Janeiro in August.

A Reuter telegram from Cape Town states that the Gauss expedition has disproved the existence of Termination Island, which is marked on maps, the expedition passing over the alleged site of the island.

THAT the Soufrière in St. Vincent is still in a state of slight agitation is recorded by Dr. E. O. Hovey (Sentry,

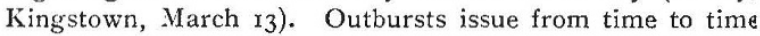
from the centre of the lake in the crater. The most impressive changes which have taken place are in the erosion of the lately-erupted volcanic material, and he estimates that twenty-five million tons have been carried to sea from the valley of the Wallibou.

WE referred last week to the demonstration of the practical working of the Marconi long-distance wireless telegraphy given by Prof. Fleming during his lecture at the Royal Institution. Prof. Fleming has written to the Times complaining that the experiments were made particularly difficult to carry out towards the end of the lecture as the signals were being wilfully interfered with by an outside source. Mr. Nevil Maskelyne, in a reply to Prof. Fleming's letter, admits that he was the author of the interference, which was designed to demonstrate that the Marconi Company was not justified in its claim that it had solved the question of interference. A lecture at the Royal Institution scarcely seems a suitable occasion for settling commercial or semi-scientific disputes, nor can the result of the experiment be regarded as convincing. It shows, no doubt, that it is possible for an outsider to interrupt the signalling, but then it is also possible to throw stones at telegraph wires and break them; it does not demonstrate that two different systems working legitimately side by side would interfere with one another when the ordinary precautions necessary in commercial work were being taken.

LAST week telephonic communication was opened between London and Brussels. The line is particularly interesting, as the submarine portion forms the longest submarine telephone cable yet laid. The total length from St. Margaret's Bay (Dover) to La Panne, Belgium, is a little more than forty-seven miles; this is rather more than double the length of the Dover-Calais cable (twenty-three miles), which forms part of the London-Paris telephone line. The cable was made by Henley's Telegraph Works, and was laid in three sections by the Alert and the Monarch, the two joints being made at sea. The Alert laid $16 \frac{1}{2}$ miles of cable, chiefly in the shallow water off the Belgian coast, the remaining $30 \frac{2}{2}$ miles being laid by the Monarch; the cable crosses one of the Anglo-Belgian telegraph cables in deep water at about one-third of the total distance from La Panne. The length of the whole line from London to Brussels is 2 ro miles, made up as follows : -83 miles overhead lines in England, 80 miles overhead lines in Belgium, and 47 miles submarine cable.

THE promoters of the mono-rail high speed electric railway between Liverpool and Manchester hope to be able to start the work of construction this summer. When the railway is completed, a service of trains running at IIO miles an hour will be started; this will reduce the time taken over the journey from Liverpool to Manchester from forty to twenty minutes. Those interested in the scheme regard it as being the prelude to a reorganisation of express railway service throughout the country, and believe that once the possibility of working at these high speeds has been clearly demonstrated, the railway companies will be induced to build special mono-rail tracks alongside their existing lines for express services. It is already rumoured that the Great Western Railway is considering the advisability of constructing such a track for an express service between Bristol and London. In connection with high speed traction on railways, the experiments to be carried out in Germany during the next few weeks will be watched with interest. All the leading locomotive builders and electrical firms have been invited to submit designs, and trials will be made on the lines between Hamburg, Hanover and Berlin; it is hoped to attain speeds of 90 to 100 miles an hour with safety.

Mr. A. Mrex informs us that a full-grown male beluga (Delphinapterus leucas) came ashore at the mouth of the Tyne on June ro, and was captured by the salmon fishermien. It measured 14 feet 2 inches. The specimen has already been cut up by the purchasers, so that it was possible to see that the teeth numbered eight on each side of each jaw, or thirty-two altogether, and that there were 